\title{
Costs of semi-mechanized forest harvest of Tectona grandis L. F. in the brazilian Amazon
}

\author{
Luiz Fernandes Silva Dionisio ${ }^{1,2}$, Lucas Feitosa Costa ${ }^{1}$, Camila de Almeida Milhomem ${ }^{1}$, Gustavo Schwartz ${ }^{3}$ \\ ${ }^{1}$ Universidade Estadual da Região Tocantina do Maranhão, Imperatriz, MA. ${ }^{2}$ Fundação Amazônia de Amparo a Estudos \\ e Pesquisas. ${ }^{3}$ Embrapa Amazônia Oriental, Belém, PA. E-mail: fernandesluiz03@gmail.com
}

\begin{abstract}
The objective of this study was to identify the harvesting system applied for Tectona grandis and its adaptations to describe the harvesting activities, characterization of the machines used and costing. The costs raised in this work were divided by activity and cost component. The work resulted in the description of the forest felling, this being carried out using three chainsaws of the Stihl brand, model MS 660 with the chainsaw teams adjusted to the scheme $(1+1)$, an operator and a helper. As an adaptation of the system, the extraction was performed from inside the field to the storage yard, and executed with a Massey Ferguson tractor, model MF 275, of medium size with high axle, $4 \times 2$ rear-wheel drive, 75 horsepower and torque of approximately $28 \mathrm{kgfm}$ adapted with a winch and use of drag chain, a tractor driver and two assistants. Labor was the most expensive cost, representing $80.82 \%$ of the total harvest cost. Gross profit per hectare was $\mathrm{R} \$ 15,525.00$, of which $30.76 \%$ was consumed by operating costs, being labor the most significant. Selling raw logs, as it was performed in this work, significantly decreases the price of the cubic meter.

Keywords: Forestry machines; forest harvesting system; teak.
\end{abstract}

\section{Custos da colheita florestal semimecanizada em plantio de Tectona grandis L. F. na Amazônia brasileira}

\begin{abstract}
Resumo
O objetivo deste estudo foi identificar o sistema de colheita aplicado para Tectona grandis, suas adaptações, descrever as atividades de colheita, caracterização das máquinas utilizadas e o levantamento de custos. Os custos levantados neste trabalho foram divididos por atividade e por componente de custo. $O$ trabalho resultou na descrição do corte florestal, este sendo executado com o auxílio de três motosserras da marca Stihl, modelo MS $660 \mathrm{com}$ as equipes de motosseristas ajustadas para o esquema (1+1) um operador e um ajudante. Como uma adaptação do sistema, a extração foi realizada de dentro do talhão até o pátio de estocagem, e foi realizada com um trator Massey Ferguson, modelo MF 275, de tamanho médio com eixo alto, tração traseira $4 \times 2$, potência de 75 cavalos e torque de aproximadamente de $28 \mathrm{kgfm}$ adaptado com guincho e uso de corrente para arraste, um tratorista e dois rabicheiros. A mão de obra representou o maior custo, $80,82 \%$ do custo total da colheita. O lucro bruto por hectare foi de $\mathrm{R} \$$ $15.525,00$, sendo $30,76 \%$ deste, consumido por custos operacionais, do qual o mais significativo foi a mão de obra. A venda em toras brutas como foi neste trabalho diminui significativamente o preço do metro cúbico.

Palavras chaves: Máquinas florestais; sistema de colheita florestal; teca.
\end{abstract}

\section{Introduction}

Multifunctional use of forests can be considered as a source of higher forest revenues and increased potential for the use of indirect forest values (MARTYNOVA et al., 2021). Timber harvesting is an important activity in the forestry sector and forest harvesting planning requires careful analysis of the variables that influence 
machine productivity (LOPES et al., 2021). This must be well planned and managed, in order to guarantee the quality of services and products, because, whether not performed properly, it can compromise productivity, raise operational and production costs, put at risk all the silvicultural work carried out and compromise subsequent activities.

Brazil is one of the most developed countries in the forest sector due to the high productivity and lower production cost in relation to other countries, with technological advances, and favorable climate conditions for timber production (SANTOS et al., 2017). Since 1990, Brazil has promoted the mechanization of forest harvesting, optimizing costs and generating revenues in operations through the entry of machines with the use of advanced tools. The cutting of native and planted species has been carried out using the semi-mechanized method, for various purposes (PEREIRA et al., 2012). However, mechanized harvest in planted forests increased significantly the harvest quality and productivity, safety of forest workers and cost reduction (PEREIRA et al., 2015; RODRIGUES et al., 2020).

Forest harvesting is the set of operations carried out in the forest massif, which aim to prepare and take the wood to the place of transport, using established techniques and standards, with the purpose of transforming it into a final product (MACHADO, 2014). Therefore, the harvest is the work performed since the preparation of trees for felling to the transport to the place of final use. Depending on the company, planning activities, unloading of wood in the industry yard and its commercialization are also involved.

Felling is the first forest harvesting stage, with great influence on the performance of subsequent operations. The felling stage comprises the operations of felling, delimbing, debarking (optional), stump removal, bucking and pre-extraction (stacking) (Figure 1).

Figure 1. Schematic representation of the felling phases.

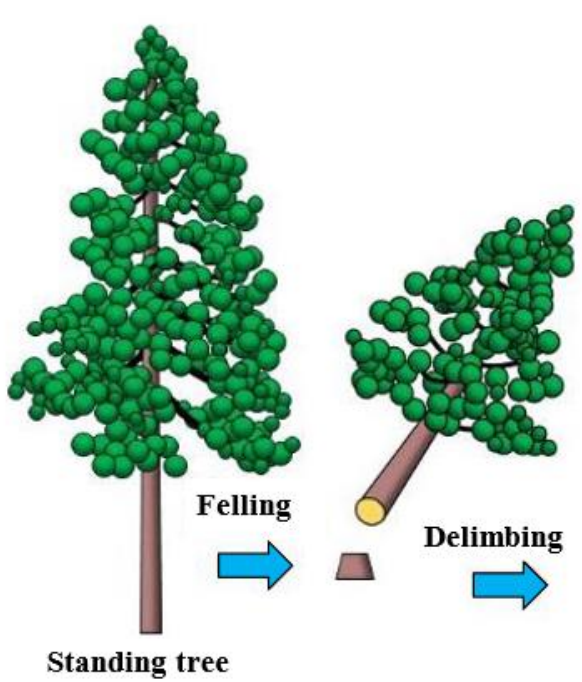

Source: (RODRIGUES, 2018).

As for: Felling $=$ the act of cutting and felling the tree to the ground; Delimbing = the act of removing branches; Stump removal = the act of removing the tree's stump; Bucking = cutting the tree into logs; Detopping = the act of removing the tree top and; Stacking = act of forming piles.

As it is an activity with high capacity to change the landscape and high financial cost, it is necessary to study effectively these activities,

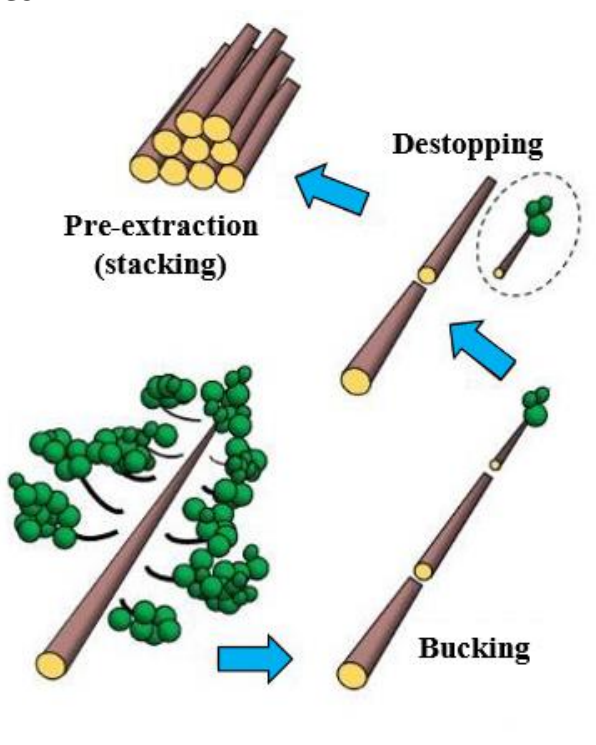

their harvesting systems and equipment available to carry it out, in order to rationalize the use of resources. The forest harvest has always been of great attention on the part of wood consuming companies, due to its high representativeness in the production costs (SOMAN et al., 2019), the high demand for labor and, also, for the exhausting nature of the work, including high accidents risks. In some cases, the costs of harvesting and transporting the forest account 
for more than $50 \%$ of the total cost of wood delivered from the factory (MACHADO, 2014).

The forest harvesting system can be influenced by several factors. Among these factors, the following stand out: relief, forest pattern, assortment and purpose of the wood, in addition to the types of machines and equipment used (RODRIGUES, 2018). Based on these factors, forestry companies choose the best methods for forest harvesting, which can be manual, semimechanized or mechanized. The method chosen will also depend on the company size.

Although the great technological benefit, the transition from the manual or semimechanized work to a totally mechanized work is a challenge. It requires high financial investments to gradually solve the modernization of forest operations. As a palliative measure to help this transition, there are: the reduction of manual entries and the general purpose machines adapted for forest use, instead of new equipment and high cost (SPINELLI, 2021).

In Brazil, especially in the North Region, harvesting systems can still vary within the forestry companies, where adaptations can be used according to the commercial cost strategies of each company. These adaptations are mostly for forest harvesting, transportation machines and equipment.

In this context, studies describing harvesting systems in small and medium-sized forestry companies in the Amazon region are scarce. In this study, the activities of harvesting, extracting, transporting and marketing timber in Fazenda Monte Santo, municipality of Boa Vista, Roraima, Brazil were characterized. Therefore, the objective of this study was to identify the harvesting system applied, its adaptations, describe the harvesting activities, description of the used machines and the costing. With these objectives, the following hypothesis was tested: the company's highest costs are with workers' labor.

\section{MATERIAL AND METHODS}

\subsection{Characterization of the study area}

The study was carried out in Fazenda Monte Santo (Figure 2), located in the municipality of Boa Vista - RR, northern region of the state of Roraima. The climate is tropical or AW (hot and humid) according to the Köppen classification, with average temperature of 27.2 ${ }^{\circ} \mathrm{C}$ and average annual rainfall of $1,534 \mathrm{~mm}$. The company Florest Plan, responsible for the harvesting work, was founded in 2018 and has two direct and ten indirect employees. All production was directly exported in raw logs for the furniture industry in Mangalore, India.

Figure 2. Location of the study area at Fazenda Monte Santo, in the municipality of Boa Vista, Roraima, Brazil.
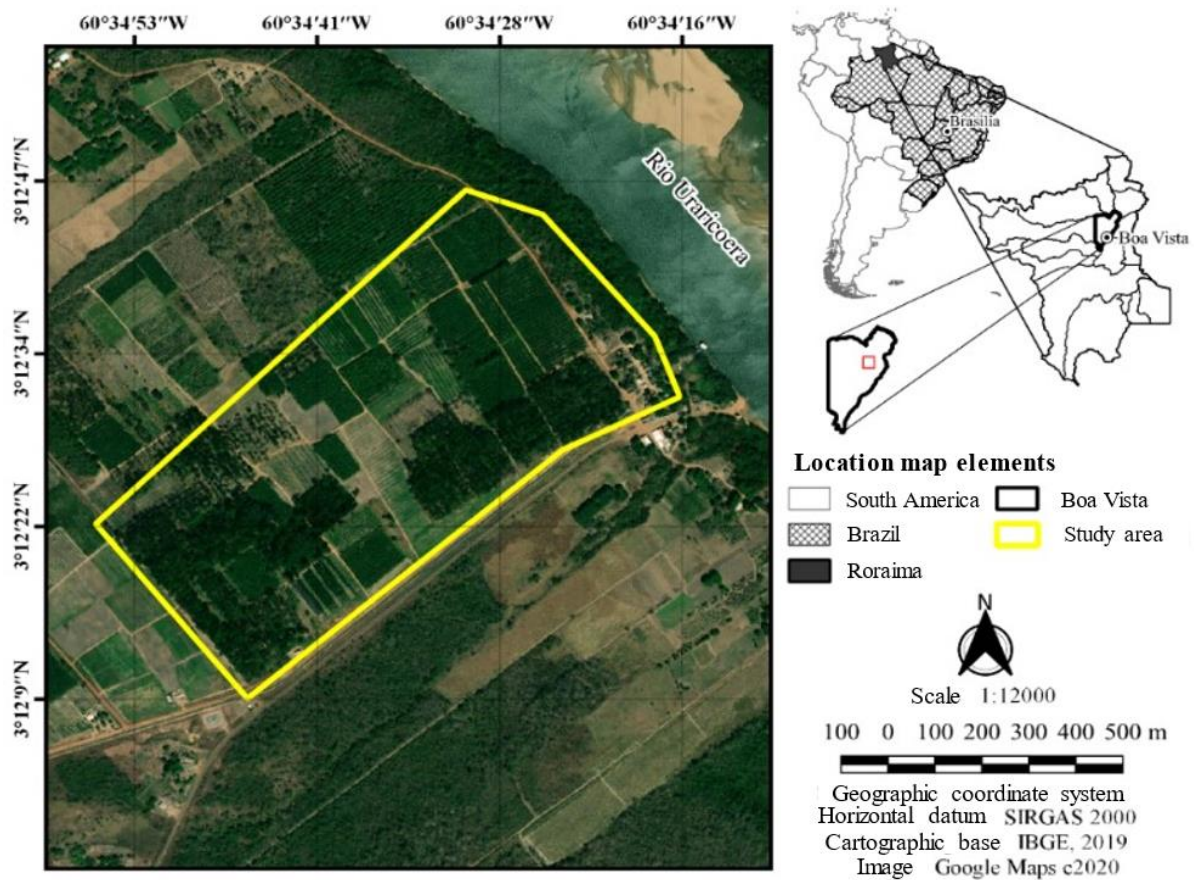


\subsection{Production units}

The present study was developed in a teak (Tectona grandis) plantation with approximately 18 years of age in an area of $10 \mathrm{ha}$. The planting spacing was $5 \times 8 \mathrm{~m}$ between trees. The average diameter of individuals, according to the forest inventory, was $92 \mathrm{~cm}$ and the average commercial height was $6.2 \mathrm{~m}$. Initially, the 10 ha planted were subdivided into 2.5-ha plots in order to facilitate the felling operations and optimize the extraction operation. Later, the felling was carried out in one plot at a time.

To describe the activities of forest harvest, used machines, harvesting system, as well as the costs involved in the process, all stages were monitored by a forest engineer, who recorded through photos and notes in spreadsheets, each of the execution phases of these activities.

\subsection{Cost analysis}

Operating costs refer to the sum of all costs resulting from the machine acquisition and operation, expressed in effective hours of work. In this work, the operational costs were estimated by the methodology of Machado and Malinovski (1988). In this methodology, costs are classified into cost components, where equipment costs are composed of: a) machinery costs (fixed and variable costs); b) labor costs; and c) administration costs. Thus, the final cost is a sum of these components, obtained by the equation 1:

$$
\mathrm{CT}=(\mathrm{CF}+\mathrm{CV})+\mathrm{CAD}+\mathrm{CMO}
$$

(1)

$$
\begin{aligned}
& \text { Where: } \\
& \mathrm{CT} \text { = total costs; } \\
& \mathrm{CF}=\text { fixed costs; } \\
& \mathrm{CV}=\text { variable costs; } \\
& \mathrm{CAD}=\text { administration costs and; } \\
& \mathrm{CMO}=\text { labor costs. }
\end{aligned}
$$

Following are shown the math formulas used to determine operating costs.

\subsubsection{Fixed costs}

\subsubsection{Taxes}

The Federal Law 6,938, of August 31, 1981, reinforced by the Normative Instruction of
IBAMA 10/01, obliges all owners to issue chainsaw license and use (LPU) (Equation 2).

$\mathrm{I}=\mathrm{Ia} \div \mathrm{Hf}$

As for:

I = taxes;

la = annual taxes (R\$), in this case, the annual license to use the chainsaw (R\$ 35.00) and; $\mathrm{Hf}=$ effective hours of annual use.

\subsubsection{Depreciation}

Depreciation is a way of recovering the original investment of equipment. Here, linear depreciation is used according to equation 3.

$\mathrm{D}=(\mathrm{Va}-\mathrm{Vr}) \div \mathrm{H}$

Where:

$\mathrm{D}=$ depreciation;

$\mathrm{Va}=$ equipment purchase price $(\mathrm{R} \$)$;

$\mathrm{Vr}=$ residual value $(\mathrm{R} \$)$ and;

$\mathrm{H}=$ economic life of the machine equipment (total hours).

\subsubsection{Variable costs}

These are the costs that vary, proportionally, due to the production or use of the equipment, such as the costs of fuel, lubricants, hydraulic oil, tires, personnel remuneration, maintenance and repairs.

\subsubsection{Fuel}

This cost was calculated by multiplying the average hourly consumption of each machine, according to its average in the study of times, by the current market price of fuel with two-stroke oil (Equation 4).

$$
\mathrm{cC}=\mathrm{Cb} \text { (measured) } \times \mathrm{p}
$$

(4)

Where:

$\mathrm{CC}$ = fuel cost;

$\mathrm{Cb}=$ fuel consumption per effective hour of work (L He-1) and;

$P=$ current market price $(R \$)$. 


\subsubsection{Hydraulic oil}

It is the cost related to the consumption of hydraulic oil. This can be calculated based on the $50 \%$ fuel cost index, adopted for all machines (Equation 5).

$$
\mathrm{OH}=\mathrm{IOH} \times \mathrm{Co}
$$

Where:

$\mathrm{OH}=$ cost of hydraulic oil (R\$/he);

IOG = hydraulic oil cost index (\%) and;

Co $=$ fuel costs $(R \$ / h e)$.

\subsubsection{Labor costs}

These are variable costs, being formed by the direct and indirect costs with the machine operator, obtained by (Equation 6). For calculation purposes, the social charges factor of $78 \%$ over wages was adopted.

$$
\mathrm{CMO}=12 \mathrm{XSm}(1+\mathrm{s}) \div \mathrm{Hf}
$$

Where:

$\mathrm{Sm}=$ monthly salary;

$\mathrm{S}=$ social charges factor $(0.78)$ and;

$\mathrm{Hf}=$ effective hours of annual use.

\subsubsection{Administration Costs}

According to Rodrigues (2018), the index (K) varies from $5 \%$ to $15 \%$ of machine and personnel costs. These are indirect costs, related to the administration of labor and machinery. In this case, $k=5 \%$ was adopted, according to equation 7.

$$
\mathrm{CAD}=\mathrm{CD} \times \mathrm{K}
$$

Where:

$C A D=$ administration costs;

$\mathrm{CD}=$ direct costs of machinery and labor and;

$\mathrm{K}=$ coefficient of administration $=5 \%$.

\section{RESULTS AND DISCUSSION \\ 3.1 System characterization}

In this study, the harvest system applied was that of short logs (cut-to-length) adapted to the property reality and the wood destination. This system can be used both in the manual method, as in the semi-mechanized or mechanized method. In Brazil, the main forest harvesting systems are short logs (cut-to-length) and full trees. In the cut-to-length system there is the employment of forest tractors harvesters and forwarders. In the full trees systems there is the employment of forest tractors as feller bunchers, skidders and harvesters (LEITE et al., 2020; SANTOS, 2021). Harvest comprised the stages of felling, delimbing, stump removal and bucking (Figure 3), still inside the plot. All of these steps were performed using the chainsaw. In order to meet the demand of the consumer center for the wood produced on the farm, the trees were cut in predefined sizes: $2.30 \mathrm{~m} ; 2.60 \mathrm{~m} ; 2.80 \mathrm{~m} ; 3.30$ m; $3.60 \mathrm{~m} ; 3.80 \mathrm{~m} ; 4.20 \mathrm{~m} ; 4.60 \mathrm{~m} ; 4.80 \mathrm{~m} ; 5.20$ $\mathrm{m} ; 5.80 \mathrm{~m}$ and $6.20 \mathrm{~m}$. 
Figure 3. Teak (Tectona grandis) harvest stages at Fazenda Monte Santo, in the municipality of Boa Vista, Roraima, Brazil. a) tree felling procedure, b) delimbing, c) stump removal, d) manual stacking and e) piled trees.
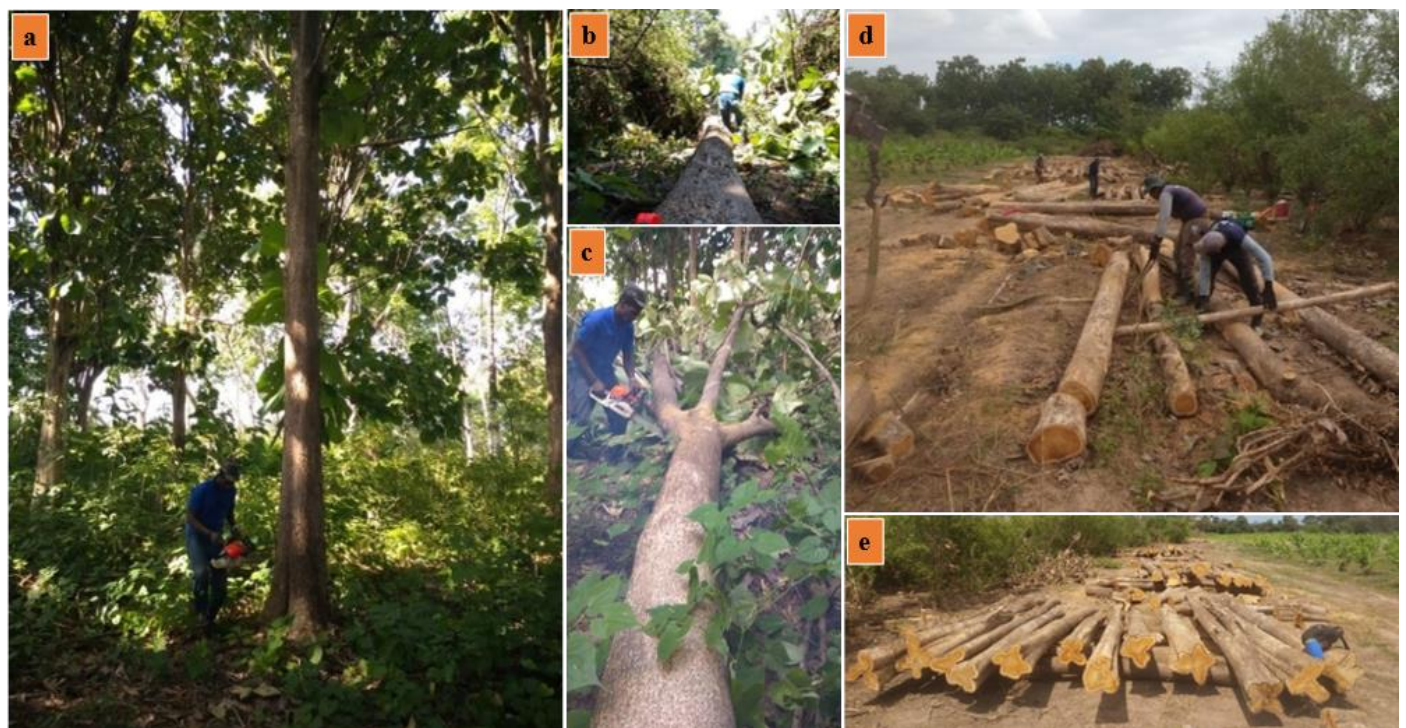

Several studies have focused on the evaluation of mechanized and semi-mechanized cultivation systems for timber production (HEIDARZADEH et al., 2008; BONAZZA et al., 2020). In the semi-mechanized system, the tree is felled and processed inside the plot, with the wood transported to the roadside or intermediary log deck in the form of logs between one and six meters in length. The main advantages of this system are the suitability in thinning, lower environmental impact in relation to soils, lesser nutrients export and easier wood handling. As disadvantages, it can be mentioned: high risks of accidents and physical effort; inadequate ergonomics (hard and dangerous activity with operations that demand work under uncomfortable positions and with repetitive movements during long periods); low productivity compared to mechanized; and inability to work in shifts. Furthermore, the activity is done under handling of heavy loads, machines and sharp tools such chainsaws (SILVA et al., 2020).

\subsection{Harvesting machines}

\subsubsection{Felling (semi-mechanized)}

Teak was harvested with three chainsaws of the brand Stihl ${ }^{\circ}$, model MS 660. This model has an excellent weight/power ratio in its category, only $1.41 \mathrm{~kg} / \mathrm{Kw}$, power of $5.2 \mathrm{~kW}$ (7.1 DIN-PS), 91.6 cylinder capacity and weight of $7.3 \mathrm{~kg}$ (Figure 4). 
Figure 4. a) Chainsaw of the brand Stihl ${ }^{\circ}$, model MS 660 used in the operations of felling, b) detopping, c) stump removal and bucking of teak (Tectona grandis) at Fazenda Monte Santo, in the municipality of Boa Vista, Roraima, Brazil.

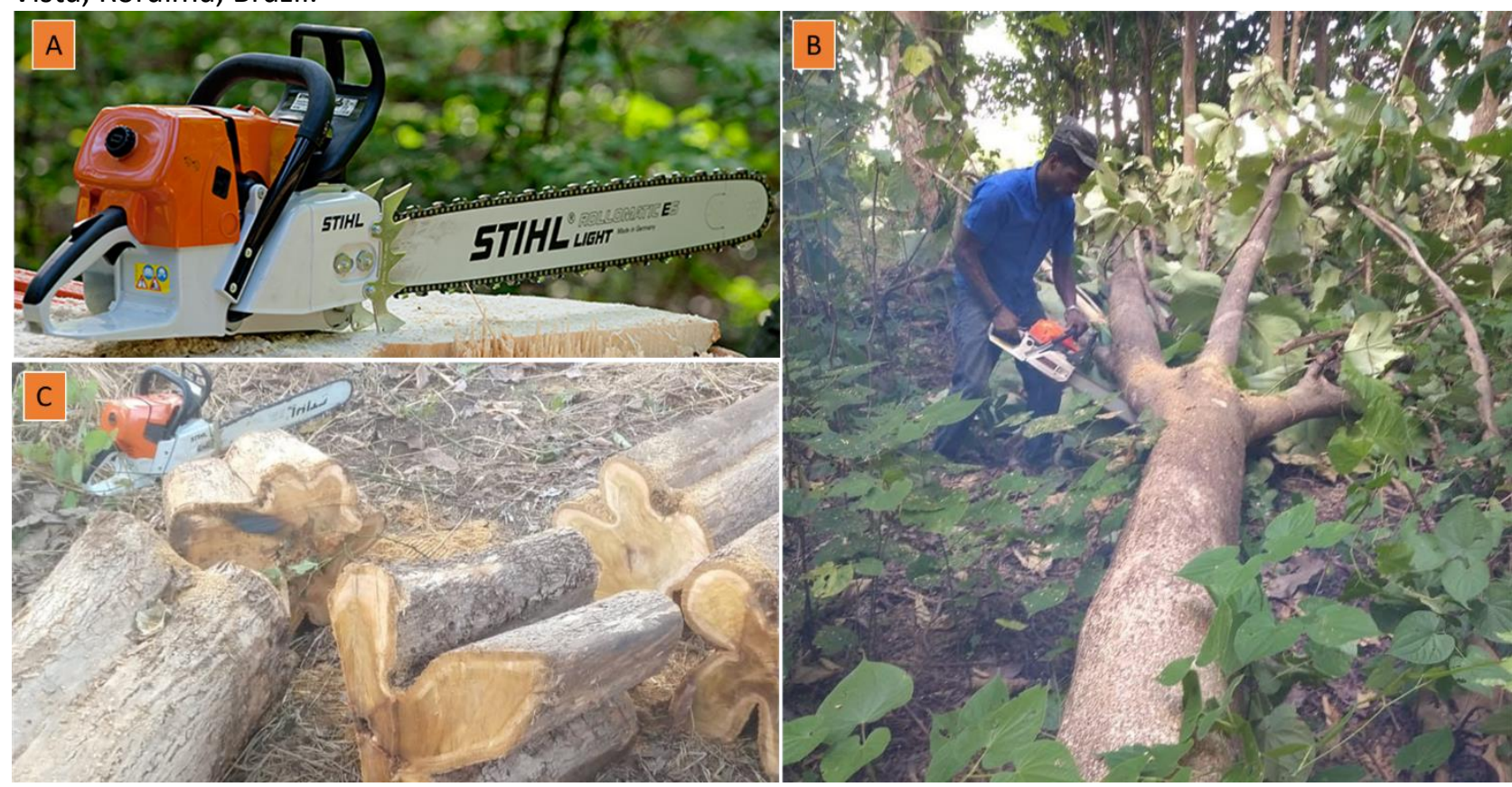

The semi-mechanized harvest is that carried out with chainsaws, a method still employed in small medium forest companies, which demands large numbers of workers (MASIOLI et al., 2020). The semi-mechanized method uses the chainsaw to execute the steps of felling, delimbing, stump removal and bucking of the wood, with a low operating cost, being able to cut and process the trees in any type of terrain (LEITE et al., 2014). The main advantages are the low acquisition cost of the machinery, performance in any topographic condition and high productivity compared to the manual method. The disadvantages are the high level of noise, physical effort, risk of accidents and low productivity in relation to mechanized methods. The use of the chainsaw proved to be multifaceted, therefore, it is possible to use it in several phases of the process, from felling, going through delimbing up to bucking.

The use of chainsaw has several advantages: low acquisition cost; performance in any terrain; execution of several operations with the same machine; and high individual production compared to the manual method. Rodrigues (2018), points out to safety precautions when using this type of equipment, the need of adequate training for operators, in order to maximize the quality, performance and ergonomics of employees.
In the felling operation, the system of work teams was adjusted to scheme $1+1$ (a chainsaw operator + an assistant). Such arrangement is the most common in the forestry sector and has low costs, good productivity with reduced number of people, implying less accident risks (NOGUEIRA et al., 2011).

\subsubsection{Extraction}

Due to the smaller diameters achieved by teak compared to other tree species, the extraction was reached with one tractor driver, operating with a Massey Ferguson ${ }^{\circ}$ tractor, medium size MF 275 model with high axle, $4 \times 2$ rear traction, 75 horsepower and torque of approximately $28 \mathrm{kgfm}$, adapted with a winch and drag chain (Figure 5a). In the system used, the wood extracted via an adapted tractor was hoisted from the inside of the plot to its margins, operationally similar in eucalyptus harvests, taken to the storage yard with the same tractor (Figure 5b). 
Figure 5. Timber extraction with drag tractor and steel cable figure a), and b) wood stacked on the margin of the teak (Tectona grandis) plot at Fazenda Monte Santo, in the municipality of Boa Vista, Roraima, Brazil. a) operation with tractor adapted with a winch and drag chain and b) trees piled on the side of the road.

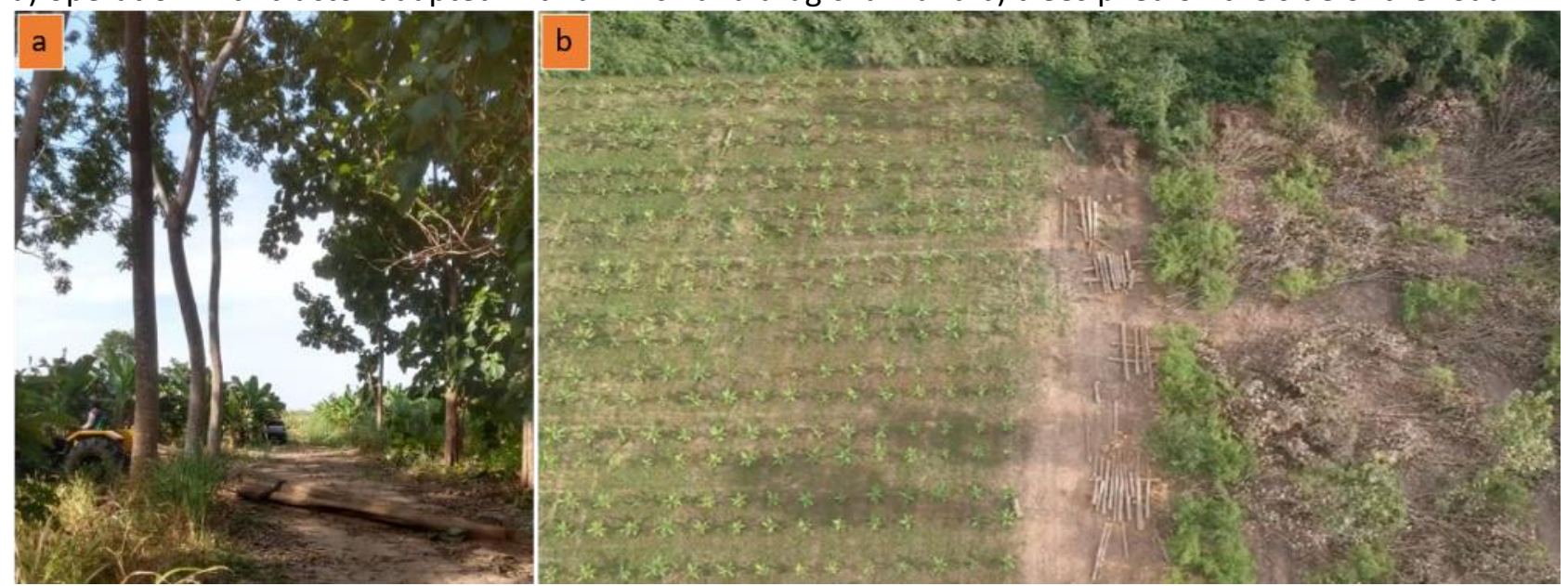

Timber extraction is one of the most complex phases and requires rigorous planning, due to the influence of several factors that directly affect productivity and production costs, such as population density, extraction distance, types of machines and level of experience of the operator.

The extraction phase includes the wood movement from the cutting site to the road or to the intermediate log deck. The main influencing factors in the extraction process are: plot density; topography; soil type; volume per tree; and transport distance. The term extraction can be replaced by a few synonyms, which are related to the mode performed or the type of equipment used. These can be classified as follows: (a) Loading: extraction of wood with the absence of contact of the logs with the soil, carried out through the use of platforms; (b) Groundskidding systems: extraction of wood where a part, or the whole, rests on the ground; and (c)
Cable systems: wood extraction with partial, total or zero contact with the ground (RODRIGUES, 2018).

For Rodrigues (2018), the extraction method with an agricultural tractor has some advantages, among them: lower machine acquisition value and easily available technical assistance. However, such method presents lower performance in relation to that of forestry tractors.

\subsubsection{Transport}

In this study, transport operations were restricted to loading the trucks of the company contracted to transport wood to the port. This operation was carried out by a Munck truck of the brand Ford ${ }^{\circ}$, model F 12000 . The activity consisted of using a crane attached to the loading vehicle to lift the logs (Figure 6). 
Figure 6. Munck truck Ford ${ }^{\circ} \mathrm{F} 12000$ loading and transporting teak (Tectona grandis) wood at Fazenda Monte Santo, in the municipality of Boa Vista, Roraima, Brazil.

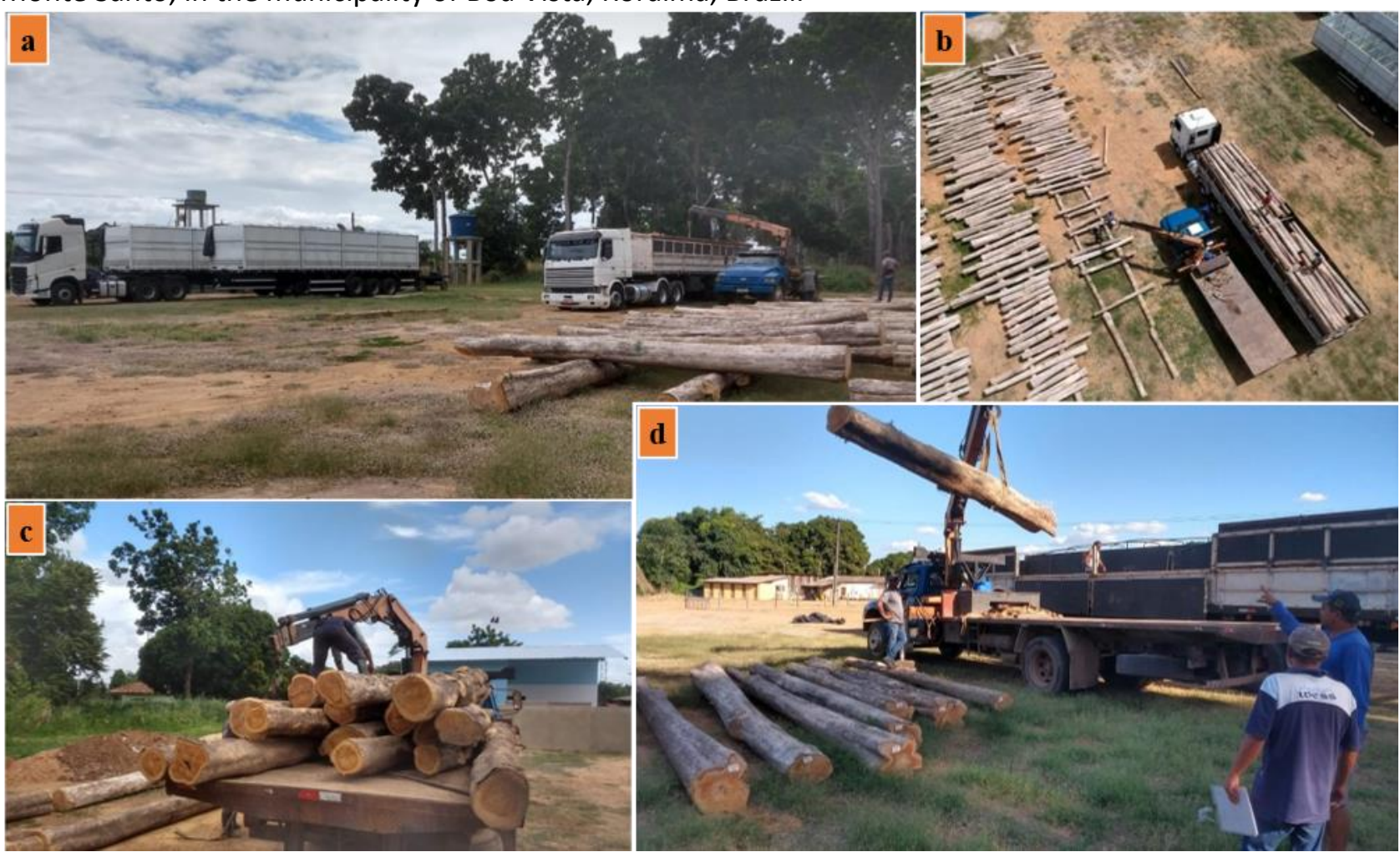

Transport is an intermediate consumption service, whose purpose is to move cargo between different locations, contributing to reduce distances and allow the exchange of consumer goods (MACHADO et al., 2011). Forest transport is understood as the movement of timber products with forest origin to consumer centers.

With the absence of its own fleet and aiming at cost reduction and higher quality, the property management outsourced the transportation of logs to the port for a final shipment to Mangalore, India to a second company. This routine is out of the competence of the contracted Florest Plan, which executed only the harvest. The process of outsourcing harvesting and transportation activities is a good example on what happens in the Brazilian forestry sector (SOUSA et al., 2018). According to Bracelpa (2008), in 2007, approximately $85 \%$ of the labor employed in the forestry activity is hired the industries of paper and cellulose came from outsourced companies.
While some companies choose to outsource only part of the activities, others transfer the entire process to third parties. Machado et al. (2011) emphasizes that the tendency of companies is to seek excellence in their activities, concentrating efforts on the improvement and development of their final product. Some reasons for companies to adopt the outsourcing of their activities means: focus on the areas that generate competitive advantages, improvement in the quality of products and or services and sharing of operational and financial risks.

\subsection{Haverst costs}

\subsubsection{Costs with semi-mechanized felling}

Costs involved in harvesting teak were provided by the harvest technician responsible for the company Florest Plan. Table 1 shows the values used in the calculation of the operating cost of forest cutting with chainsaw. 
Table 1. Values used in the calculation of the operating cost in teak (Tectona grandis) felling at Fazenda Monte Santo, in the municipality of Boa Vista, Roraima, Brazil.

\begin{tabular}{lccc}
\hline \multicolumn{1}{c}{ Items } & Unitary value & Quantity & Total value \\
\hline Depreciation & 42.96 & 3 & 128.88 \\
Chainsaw license (R\$/year) & 35.00 & 3 & 105.00 \\
Fuel cost (R\$/L) & 4.29 & 312 & $1,338.48$ \\
Two-stroke oil cost (R\$/L) & 36.00 & 10 & 360.00 \\
Chainsaw chain & 85.00 & 38 & $3,230.00$ \\
Chainsaw sharpener (3 boxes) & 159.00 & 3 & 477.00 \\
Chainsaw maintenance & $1,134.00$ & - & $1,134.00$ \\
Chainsaw operator salary (R\$) & 867.00 & 3 & $2,600.00$ \\
\hline \multicolumn{1}{c}{ Total } & & & $\mathbf{9 , 3 7 3 . 3 6}$ \\
\hline
\end{tabular}

There are two major groups of costs related to forest felling, the variable costs represented by fuels, maintenance and parts contributed almost half of the final value, totaling $48.60 \%$ and labor costs, with $49.65 \%$ of the total cost with the felling.

Forest harvesting has always been of great attention from wood consuming companies, due to its high representativeness in the production costs, high labor demand and, also, the exhausting nature of the work, followed high accidents risks. In some cases, the costs of harvesting and transporting the forest account for more than $50 \%$ of the total cost of wood shipped from the factory (MACHADO, 2014).

The form and determinants of economic cost functions for forest processing are well

Table 2. Values used to calculate the operating cost of teak (Tectona grandis) forest extraction at Fazenda Monte Santo, in the municipality of Boa Vista, Roraima, Brazil.

\begin{tabular}{lccc}
\hline \multicolumn{1}{c}{ Items } & Unitary value & Quantity & Total value \\
\hline Assistant salary (R\$) & $2,040.00$ & 2 & $4,080.00$ \\
Machine hour/tractor operator (R\$) & 110.00 & 112 & $12,320.00$ \\
\hline Total & & & $\mathbf{1 6 , 4 0 0 . 0 0}$ \\
\hline
\end{tabular}

\subsubsection{Transportation costs}

Transport costs (Table 3 ) were also borne by the producer, following the FOB (Free On known. According to Engler et al. (2016), it is important to express costs to demonstrate the economic effects of mechanization of harvesting operations and to identify activities in which mechanization is reasonable and provides greater benefits.

\subsubsection{Costs with forest extraction}

The main costs involved in the extraction process refer to the machine hour value of the tractor and assistant, this is responsible for helping fastening logs on the tractor for skidding, as well as signaling correct directions (Table 2).

Table 3. Values used in the calculation of the operational cost of transporting teak (Tectona grandis) to the port, at Fazenda Monte Santo, in the municipality of Boa Vista, Roraima, Brazil.

\begin{tabular}{lccc}
\hline Items & Unitary value (R\$) & Quantity (tons) & \multicolumn{1}{c}{ Total value } \\
\hline Ton of teak & 110.00 & 178.25 & $19,607.50$ \\
\hline Total & & & $\mathbf{1 9 , 6 0 7 . 5 0}$ \\
\hline
\end{tabular}




\subsubsection{Sale value of cubic meter of teak}

The yield of the teak crop per hectare according to the pre-felling inventory was estimated at $370 \mathrm{~m}^{3}$ in the 10 ha planted. After log tracing and cubing by the Francon or Hoppus method, the volume decreased significantly (Table 4). As the teak was sold in raw logs, only cut in the predefined sizes, the price of the cubic meter decreased significantly, therefore the wood was neither sawn nor dried, which would add significant value to the final product.

Table 4. Values used in the calculation of the sale of teak (Tectona grandis) wood at Fazenda Monte Santo, in the municipality of Boa Vista, Roraima, Brazil.

\begin{tabular}{llcr}
\hline Items & Unitary value & Amount $\mathbf{~ ( ~}^{\mathbf{3}}$ hoppus) & Total value \\
\hline $\mathbf{m}^{\mathbf{3}} \mathbf{( R \$ )}$ & $1,350.00$ & 115 & $155,250.00$ \\
\hline Total & & & $\mathbf{1 5 5 , 2 5 0 . 0 0}$ \\
\hline
\end{tabular}

\subsubsection{Components of the operational cost of the} harvest

Applying the FAO methodology according to Machado and Malinovski (1988) proposed in this work, the following percentages by cost component arrive (Table 5).

Table 5. Cost components of teak (Tectona grandis) harvest at Fazenda Monte Santo, in the municipality of Boa Vista, Roraima, Brazil.

\begin{tabular}{lc}
\hline Items & Total value (R\$) \\
\hline Fixed costs & 233.88 \\
Variable costs & $6,644.48$ \\
Labor & $38,607.50$ \\
Administration & $2,282.12$ \\
\hline Total & $\mathbf{4 7 , 7 6 7 . 9 8}$ \\
\hline
\end{tabular}

Figure 7 shows the percentages of each cost component. Fixed costs add up to just $0.49 \%$, administration costs are $4.78 \%$, variable costs $13.91 \%$ and labor costs $80.82 \%$ of the total. In absolute values, gross profit per hectare was approximately $\mathrm{R} \$ 15,525.00$, of which $30.76 \%$ was charged by operating costs, being the labor costs the most significant.

Figure 7. Percentage distribution of the components of the operational cost of the harvest, at Fazenda Monte Santo, Boa Vista, Roraima, Brazil.

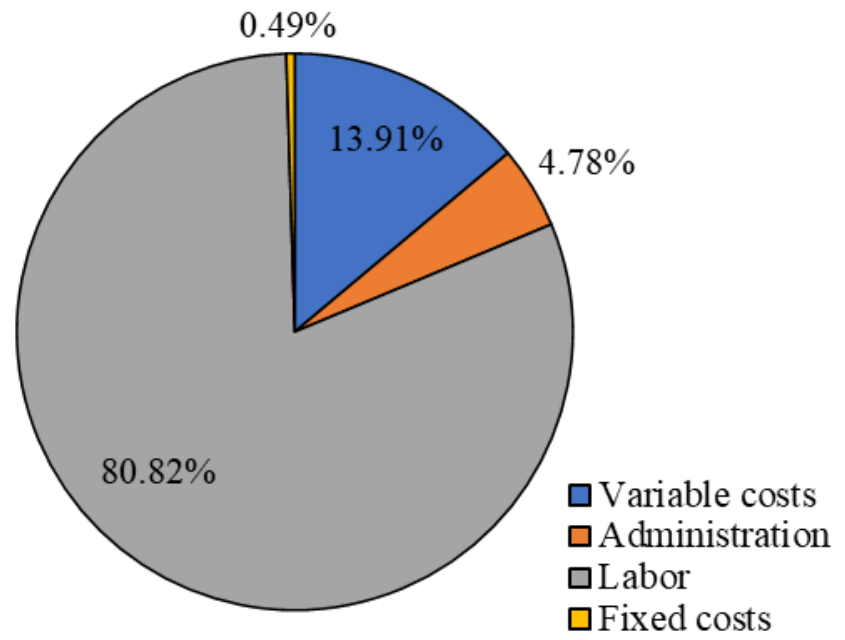


Leite et al. (2014), analyzing the costs of semi-mechanized forest felling in eucalyptus stands with different spacing also found similar values of $75 \%$ in labor costs. Vargas (2019), in an analysis of final cutting of Pinus elliottii in two relief operation conditions, found out similar values in labor costs in operations of felling and bucking in the forest stand, $57 \%$ and $65 \%$ respectively. These were values close to ours' for cutting and bucking $49.65 \%$. Such percentage can be explained by regional wage differences and planting relief conditions.

\section{CONCLUSIONS}

The results lead to the hypothesis acceptance, as labor cost contributed to $80.82 \%$ in the final cost values, showing how important is the operators training.

Teak (Tectona grandis) planting did not achieve the expected results in diameter and final volume, which contributed to the relatively low profit.

Harvesting cost per hectare reached $\mathrm{R} \$$ $4,776.75$, corresponding to $30 \%$ of gross profit.

To add value through the drying and sawing process could be an alternative to increase net profit of teak plantings.

\section{REFERENCES}

BONAZZA, M.; DOBNER JR, M.; NOVACK JR, N.S.; SAMPIETRO, J.A.; ARCE, J.E.; WOJCIECHOWSKI, J. Desempenho operacional e custos de desbaste pré-comercial semimecanizado em Pinus taeda L. Scientia Forestalis, v.48, n.125, e3064, 2020. https://doi.org/10.18671/scifor.v48n125.08.

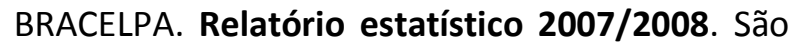
Paulo: BRACELPA, 2008.

ENGLER, B.; BECKER, G.; HOFFMANN, S. Process mechanization models for improved Eucalyptus plantation management in Southern China based on the analysis of currently applied semimechanized harvesting operations. Biomass and Bioenergy, v.87, p.96-106, 2016. https://doi.org/10.1016/j.biombioe.2016.02.021.

HEIDARZADEH, E.; ALMASSI, M.; DEHGHANIAN, S.; MOHAMMADREZAEI, R. Comparison of machinery and labor productivity of mechanized and semi mechanized and semi traditional wheat production systems in Mashhad. Journal of Economics and Agriculture Development, v.22, n.1. p.51-62,

2008.

https://www.sid.ir/en/Journal/ViewPaper.aspx?! $\underline{D=141255}$.

LEITE, E.S.; FERNANDES, H.C.; GUEDES, I.L.; AMARAL, E.J. Análise técnica e de custos do corte florestal semimecanizado em povoamentos de eucalipto em diferentes espaçamentos. Cerne, v.20, n.3, p.637-643, 2014. https://doi.org/10.1590/01047760201420041340

LEITE, E.S.; SANTOS, J.S.; GOMES, B.M.; NÓBREGA, J.C.A.; NÓBREGA, R.S.A. Compactação do solo causada pelo harvester e intensidade de tráfego do forwarder na colheita florestal. Scientia Forestalis, v.48, n.126, e3075, 2020. https://doi.org/10.18671/scifor.v48n126.21.

LOPES, I.L.E.; ARAÚJO, L. A.; MIRANDA, E.N.; BASTOS, T.A.; GOMIDE, L.R.; CASTRO, G.P. A comparative approach of methods to estimate machine productivity in wood cutting. International Journal of Forest Engineering, p.113 , 2021.

https://doi.org/10.1080/14942119.2021.1952520

MACHADO, C.C. Colheita florestal. 3. ed. Viçosa: UFV, 2014.

MACHADO, C.C.; LOPES, E.S.; BIRRO, M.H.B.; MACHADO, R.R. Transporte rodoviário florestal. 2. ed. Viçosa: UFV; 2011. 217 p.

MACHADO, C.C.; MALINOVSKI, J.R. Ciência do trabalho florestal. Viçosa: Universidade Federal de Viçosa, 1988. 65 p.

MARTYNOVA, M.; SULTANOVA, R.; KHANOV, D.; TALIPOV, E.; SAZGUTDINOVA, R. Forest management based on the principles of multifunctional forest use. Journal of Sustainable Forestry, v.40, n.1, p.32-46, 2021. https://doi.org/10.1080/10549811.2020.1734025

MASIOLI, W.; FIEDLER, N.C.; LOPES, E.S.; OLIVEIRA, F.M. Exposição de trabalhadores a ruído e vibração em atividades de colheita florestal semimecanizada. Pesquisa Florestal Brasileira, v.40, e201901703, 2020. https://doi.org/10.4336/2020.pfb.40e201901703

NOGUEIRA, M.; VIEIRA, V.; SOUZA, A.D.; LENTINI, $M$. Manejo de florestas naturais da Amazônia: 
corte, traçamento e segurança. Belém: Instituto Floresta Tropical, 2011. 21 p.

PEREIRA, A.L.N.; LOPES, E.S.; DIAS, N.A. Technical and cost analysis of feller buncher and skidder on wood harvesting in different stand productivity. Ciência Florestal, v.25, n.4, p.981-989, 2015. https://doi.org/10.5902/1980509820659.

PEREIRA, R.S.; GUIMARÃES, P.B.R.; DEL MENEZZI, C.H.S.; VALE, A.T.D.; ROBERT, R.C.G. Avaliação da segurança e ocorrência de defeitos na operação de corte semimecanizado de florestas de eucalipto. Revista Árvore, v.36, n.3, p.511-518, $2012 . \quad$ https://doi.org/10.1590/S0100$\underline{67622012000300013 .}$.

RODRIGUES, C.K. Colheita e transporte florestal. 1. ed. Curitiba: Ed. Autor, 2018.

RODRIGUES, C.K.; LOPES E.S.; MÜLLER M.M. Avaliação da qualidade estrutural do solo em colheita mecanizada (harvester e forwarder) de Eucalyptus grandis. Agrarian, v.13, n.47, p.56-62, 2020.

https://doi.org/10.30612/agrarian.v13i47.8484.

SANTOS, D.W.F.N. Desempenho operacional de máquinas florestais em função do número de dias da escala de trabalho. Revista de Ciências Agrárias, v.64, 2021. http://periodicos.ufra.edu.br/index.php/ajaes/art icle/view/3370/1615.

SANTOS, L.N.; FERNANDES, H.C.; SILVA, R.M.F.; SILVA, M.L.; SOUZA, A.P. Avaliação de custos do harvester no abate e processamento de madeira de eucalipto. Revista Árvore, v.41, n.5, p.1-9, 2017. https://doi.org/10.1590/180690882017000500001.

SILVA, L.L.; GUIMARÃES, P.P.; SILVA, A.K.V.; OLIVEIRA, J.L.R.; CARMO, F.C.D.A.; HOLANDA, A.C. Análise das posturas adotadas durante 0 corte semimecanizado de jurema preta em manejo da Caatinga. Nativa, v.8, n.3, p.442-449, 2020. https://doi.org/10.31413/nativa.v8i3.9398.

SOMAN, H.; KIZHA, A.R.; ROTH, B.E. Impacts of silvicultural prescriptions and implementation of best management practices on timber harvesting costs. International Journal of Forest Engineering, v.30, n.1, p.14-25, 2019. https://doi:10.1080/14942119.2019.1562691.
SOUSA, P.R.; LOPES, D.P.T.; ANDRADE, S.C.; RESENDE, P.T.V. Terceirização das atividades florestais na indústria de celulose e papel. RAIMED: Revista de Administração IMED, v.8, n.2, p.260-280, 2018.

https://doi.org/10.18256/2237-

7956.2018.v8i2.3115.

SPINELLI, R.; MAGAGNOTTI, N.; LOMBARDINI, C.; MIHELIČ, M. A Low-Investment option for the integrated semi-mechanized harvesting of smallscale, short-rotation poplar plantations. Smallscale Forestry, v.20, n.1, p.59-72, 2021. https://doi.org/10.1007/s11842-020-09456-3.

VARGAS, D.A. Análise da colheita florestal semimecanizada em corte final de Pinus elliottii em duas condições operacionais de relevo. 2019. 42 f. Monografia (Especialização em Gestão Florestal) - Economia Rural e Extensão, Universidade Federal do Paraná, Curitiba, 2019. 